\title{
What Does the Forest User Require from the Forest Manager
}

\author{
by
}

W.B. Gayle ${ }^{1}$

\begin{abstract}
The forest users' needs can be stated simply: "A continuous and sustained supply of wood at a constant real cost".

Forest manufacturing is highly capital intensive. A pulp mill costing $\$ 500$ million needs five 65 -milliondollar sawmills and five 35-million-dollar logging operations to supply the necessary volume of chips. The total costs $\$ 1$ billion and $\$ 150$ million per year must be put back into the business. To obtain the money, there must be not only a secure forest tenure, but for Crown lands, an incentive for wood users to make a solid commitment to forest management.

The logger needs a year-round operation with relatively consistent timber types and topography. The sawmiller needs wood of consistent size and quality at an economical hauling distance from the mill. Mills will go under if hauling distances increase year by year, hence the need for total regeneration and rehabilitation of the backlog of NSR Land. The pulp mills require raw material of consistent quality to sell pulp on the open market.

Threats to these requirements are lack of regeneration of denuded lands, ever decreasing annual allowable cuts with increased haul distances, and withdrawal of forest land from production.

The solution is to provide incentives for the user to manage the forests under contract with the owner. Then there will be long-term management - a time frame not compatible with the fiscal policies of politicians and hence governments.
\end{abstract}

Key words: forest management, forest industry, financial requirements, forest economics.

The purpose of this discussion is to identify the forest industry's requirements from Crown forest lands. What are we, in industry, looking for, assuming the Crown is the manager of such forest lands, and how might our requirements relate to those who see and use forests for wild life or recreation? The overall objective of this symposium is to promote integration of forestry and wildlife management in Canada.

\footnotetext{
TVice-president, Coast Forestry and Logging, Canadian Forest Products Ltd., Vancouver, B.C. V7X 1 B5
}

I am somewhat puzzled by these terms of reference - we are to assume that the government ministries are the "managers" and commercial interests that are authorized to remove the resources are the "users" - not managers.

Herein lies the problem - the government agencies are themselves not integrated, and we shall never achieve true integration of forest values unless the users are given the responsibility (and accountability) to manage. To be successful there must be a firm commitment by the user to manage the forest for cropping - the harvest of wood fibre, the harvest of fish and wildlife, and the "harvest" of recreational values, for a long-term sustained maximum yield. This is what is missing when each user writes a "want list" and assumes that the government agencies, as manager, will ensure that his needs are delivered.

The forest industry's needs can be stated quite simply: "A continuous and sustained supply of wood of a consistent quality at a constant real cost." Simpler said than done.

All of us appreciate that forest manufacturing is highly capital intensive. To provide wood for a $\$ 65$-million sawmill, a logger needs \$35-million worth of logging equipment and capital. A pulp mill costing $\$ 500$-million needs five $\$ 65$-million sawmills and five $\$ 35$-million logging operations to supply the necessary volume of chips. It doesn't matter whether this is financed under the umbrella of a large integrated corporation, or whether the package is made up of independent businesses - the logger selling logs at arm's length to the sawmiller, and the sawmiller selling chips at arm's length to the pulp mill. Economics forces integration of facilities, and in the above example it will take one billion dollars to provide an integrated package.

This is only for starters. To continue to be as effective as the competition, every year more money must be poured in to replace worn out or obsolete equipment, or to purchase more efficient equipment to make better products. The logger needs a new grapple yarder, a new loader or some new trucks; the sawmiller needs high technology scanning equipment or new and more efficient dry kilns; the pulp mill needs new recovery boilers, new effluent treatment plants; and so on. This billiondollar complex needs $\$ 150$ million a year ploughed back into the business just to keep alive in the marketplace. That is basic industrial economics.

Who will be willing to provide this amount of capital if there is no long-term assurance of an economical wood supply? Money will not be available initially, not will it continue to be ploughed back into the business if the wood isn't there, now 
and forever. The more secure the forest tenure, the more readily will funds flow to the business.

A secure forest tenure will not, in itself, ensure sound forest management. There must be an incentive for the users of wood to make a solid commitment to forest management, and above all, there must be some financial arrangement with the government to provide funding for regeneration and intensive forestry programs.

There is a built-in incentive in cases where the user owns the land, but with Crown land, where, by definition, the stumpage appraisal formula allocates any additional revenue, then surely the owner or the government should provide the funding. Until now, at least, this has been the case in British Columbia, and this system must be applied on Crown lands in all of Canada.

For the logging operations and manufacturing plants to be successful, the users must control not only the volume of the wood 20 years from now, but also the size and quality 20 years from now. Here are the needs of the wood user.

The Logger. The logger buys equipment that is as versatile as possible - but what is required for large, decadent, oldgrowth forests is something quite different from what is required for the new forest. No logger can survive one year faced with a steep sidehill of 400-year-old cedar hemlock, and the next year with an 85-year-old second growth fir stand on relatively flat country. You can't afford a $\$ 750000$ grapple yarder to do the job of a $\$ 120000$ rubber-tired skidder. The logger is looking for a year-round operation with relatively consistent timber types and topography.

The Sawmiller. So, too, the sawmiller designs a mill with flexibility - but a mill that is efficient for old-growth decadent wood is usually a high cost mill when it cuts second growth wood. What is more important, the sawmiller cannot stand the costs of an ever-increasing distance from wood supply to mill. Long-term planning should ensure that distant stands are developed and logged in conjunction with nearby stands, and that this balance is maintained throughout the rotation age. The old adage, "take the bad with the good," is most appropriate when planning forest development.

The Pulp Mills. Much of the above is also true for pulp mills, whether their raw material is sawmill chips or pulpwood from the forest. To work efficiently, machinery is designed for a particular size or type of log. More importantly, pulp mills sell their products to markets that demand a consistent product in fibre quality, in strength, in colour. If a mill cannot provide consistent quality, its customers will buy from another mill that can

All the above supports the statement that the wood user needs "a continuous and sustained supply of wood of a consistent quality at a constant real cost."

What are the present threats to this requirement? There are several; all relating to the diminishing forest land base.

\section{Lack of Regeneration of Denuded Lands}

The one threat that most people do understand is the lack of regeneration after logging or denudation from fires, insects or disease. We can only keep our "capital" forest intact if, every year, the denuded areas are regenerated.

In Canada, we are regenerating only $62 \%$ of annual depletion. This means that after one rotation, say 100 years, we have only $62 \%$ of our forest left for the second rotation. Our allowable annual cut, or "interest," is also reduced to $62 \%$ of our present allowable annual cut. That is a reduction of slightly less than $0.5 \%$ per year. There is a current backlog of 26 million ha and this is increasing by 300000 ha per year.
In British Columbia we are doing better: we are regenerating $84 \%$ of annual depletion. This means that after one rotation, say 100 years, we have $84 \%$ of our forest left for the second rotation. Our allowable annual cut is reduced to $84 \%$ of the present. This represents an allowable annual cut reduction of only $0.16 \%$ per year. There is a current backlog of 675000 ha, and this is increasing by 27000 ha per year.

The overall picture indicates a critical situation. It is necessasry, first, to increase our planting projects so that our restocking equals our annual depletion. Then we must expand our reforestation program to reduce the backlog of past deficiencies. This second phase is often very costly because much of this backlog is now covered with brush, shrubs, and noncommercial cover such as aspen, maple and alder. To prepare this ground for planting requries application of herbicides, a practice that has not yet found favour with many environmentalists. Yet cleaning out this brush manually is costly and the results are usually only temporary.

In British Columbia only $84 \%$ of the annual depletion is being restocked. Let's analyze the problem by tenure and region:

\begin{tabular}{lccc}
\hline & $\%$ & $\%$ & $\%$ \\
& Coast & Interior & $\begin{array}{c}\% \\
\text { Total }\end{array}$ \\
\hline Tree farm license & 100 & 80 & 89 \\
Timber supply area & 95 & 80 & 82 \\
\hline Total & 96 & 80 & 84 \\
\hline
\end{tabular}

Primarily, then, the government is responsible for expanding the provincial program to fund reforestation in the timber supply areas, partaicularly in the interior. The deficit is largely the result of insufficient trees available for planting

On a national scale, if the rate of restocking in Canada is not tripled, by the turn of the century Canada will face a massive timber shortage.

\section{Withdrawal of Forest Land}

The second concern relating to our future wood supply is the continuing reduction of the forest land base. This takes away from our forest "capital" and reduces the allowable annual cut. Every year, parts of some managed forest are withdrawn for parks, ecological reserves, winter ranges for deer and caribou, hydro reservoirs, highways, and power lines. This is an even greater threat to our future timber supply than lack of reforestation because, once lost, it is usually gone forever. There is no "backlog" to bring back at a later date.

This concept is not clearly understood by the public indeed, even our legislators. Some people think that when a patch of timber is made into a park there is no net loss because the timber is still there. That statement was made by a cabinet minister in all sincerity. The fact is, of course, that as soon as timber land is withdrawn from a managed forest area, no matter if that land contains mature timber or a 15-year-old second growth stand, the allowable annual cut is reduced immediately, production is curtailed, people are put out of work.

During the last 10 years, $16 \%$ of the forest land base has disappeared. Over the next 20 years, a $25 \%$ reduction is forecast. Granted, part of this land is composed of environmental protection areas and areas considered inaccessible. However, if this is true, in 30 years we shall face a reduction of over $40 \%$, or $1.4 \%$ per year. 
In British Columbia, this reduction of our allowable annual cut due to withdrawal of forest lands ( $1.4 \%$ per year) is almost 10 times the reduction of the allowable annual cut due to lack of regeneration $(0.16 \%$ per year).

What is the answer? How can we offset these threats, and manage the forest to meet the needs of all users? Of course, finding that answer is the purpose of this symposium, but I am tempted to offer some suggestions.

We are now facing a massive timber shortage because, in general, governments have not been able or willing to provide funding for sound forest management. The short-term perspective of the politician and the even shorter-term fiscal policies of government do not permit government agencies to manage the forest properly on a site-specific basis. Just compare forest practices in most of Canada with the good forest practices in countries where much of the forest land is owned outright by the wood user. In Sweden, where there is greater growing stock now than ever before, only $25 \%$ is owned by the state. In British Columbia the province owns $95 \%$ of the forest land, and each year there is less growing stock.

In Canada, the areas of public forests that have been managed to an acceptable standard are in long-term tenures, such as tree farm licences in British Columbia, and similar tenures in Alberta and Nova Scotia.

By insisting that the wood user properly manage all values of the forest in return for a secure and consistent timber supply, and a funding formula to manage the forest on a long-term basis, we can meet the needs of all users.
To resolve the issue, and to implement effective management of all resources of the forest, in Canada we should:

1. Create forest management units and "lease" area(s) to the wood user for forest management on a long-term (25-year) tenure.

2. Treat costs of basic and intensive management as an operating cost and make provision for funding on a longterm basis. Management would include not only management in a silvicultural sense, but enhancement of wildlife, fish, recreation, and water quality. All this must be funded before the government creams off the "surplus" in the form of stumpage.

3. Integrate government jurisdictions so that forests, wildlife, fish and lands are administered under one minister and one deputy minister.

4. Define specific objectives and standards of performance for best mix of "products" from the forests - silviculture, log harvesting, fish and wildlife, recreation - and delegate full authority to the forest user to achieve the standards.

Then we shall achieve high standards of forest management - intensive forest practices, consideration of fish and wild life values based on nonemotional benefit/cost comparisons, balanced logging plans to achieve a consistent harvest of all forest values on a long-term basis. Part of this concept is already working in British Columbia. All that is required is to extend this concept to other forest disciplines, and throughout Canada.

\title{
Integrating Forestry and Wildlife Management: The View of the Private Land Timber Resource User
}

\author{
by
}

\author{
P.P. Hynard 1
}

\begin{abstract}
The users of the private land timber resource include the landowner (who uses it for property income), the logger, and the mills dependent on local timber supply.

The objectives of landowners vary considerably, as do their dependence on timber sales for income and their use of the property for personal recreation. Loggers tend to view forestry-wildlife integration unfavourably wherever this results in increased logging costs. The forestry interests of the local mills are similarly those of timber availability, wood procurement costs and freedom from disruption of supply.
\end{abstract}

Key words: Forest management, private forest lands, integrated land management, wildlife management.

\section{Who are the Timber Resource Users?}

The purpose of my paper is to represent the timber resource user's view on the integration of forestry and wildlife manage-

'Management Forester, Ontario Ministry of National Resources, Minden, Ontario $\mathrm{KOM} 2 \mathrm{KO}$ ment on private lands. In reality there are several timber resource users: the landowner, who uses the timber resource for property income; the logger, who uses it for a livelihood, and the mills dependent on local timber supply.

I shall attempt to present each of their views separately, and follow this with a case study of Haliburton County, which is located to the immediate south of Algonquin Park in Ontario.

\section{The Landowners}

The objectives of landowners vary considerably. So do their use of the standing timber resource for income and their use of the property for personal recreation. There are exceptions, it seems, to all of the generalizations that follow.

Large tracts of land are often company- or corporationowned. In this case timber revenues may be important to the owner to pay for access development, land taxes, and other costs of holding land pending the development of lakeshore property or other speculative values. In some cases the land is held by a forest industry as a source of timber supply or as a last-resort supply reserve. It may even represent a sustained yield timber production unit, although this is unusual in eastern Canada.

Where lakeshore properties have already been developed and severed from the hinterland parcel or where no such potential exists, stumpage values may represent a high por- 